\title{
NCSTN Gene
}

National Cancer Institute

\section{Source}

National Cancer Institute. NCSTN Gene. NCI Thesaurus. Code C162432.

This gene is involved in the regulation of gamma-secretase activity. 